\title{
Illicit crops substitution and rural prosperity in armed conflict areas: A conceptual proposal based on the Working With People model in Colombia
}

\author{
Carlos Alberto Avila Ceron , Ignacio De los Rios-Carmenado , Susana Martín Fernández
}

\begin{abstract}
A B S T R A C T
The methods of substituting illicit crops in conflict areas have been debated at an international level in various studies. However, not many studies have focused on the effects of substituting illicit crops with regards to the concept of rural prosperity. The paper presents a new methodological focus for substituting illicit crops in conflict areas, based on the "Working with People" (WWP) model. It incorporates expert knowledge relating to planning activities for substituting illicit crops, and links between prosperity and rural development. The study is based on a region of Colombia called La Macarena. The social base consists of 2503 families affected by the historic conflict involving illegal armed groups (FARC) for more than 50 years. We present the different phases and historic milestones that have occurred in relation to Alternative Development policies in Colombia (1964-2016). The empirical evidence presented indicates that WWP model provides process of social learning, and can be effective for substituting illicit crops, to alternative development projects by the public and private sectors. Establishing trust by working with people was the main condition, which facilitated the creation of prosperity and rural development with a sustainability vision.
\end{abstract}

\section{Introduction}

The problem of illicit crops has generated global interest for many years (Vargas, 2002), leading to many governments adopting anti-drug policies (Steven, 2000; Singer, 2008; Ritter, 2009; Gootenberg, 2012). As with other armed conflicts (ONU, 2013), the problem is closely linked to the desire to control the natural resource of land (Clemencia et al., 2005; FAO, 2012; Gómez and Soto, 2013). The problem is also related to the global context (Grisaffi and Ledebur, 2016) and some authors (Gootenberg, 2014) refer to the so-called "balloon effect", so that the successes of a country's illicit crop policies can shift illicit production to other borders. In the face of these conflicts and in light of the need to improve land ownership governance, the FAO implements the Voluntary Guidelines on the Responsible Governance of Tenure of Land, Fisheries and Forests in the Context of National Food Security (FAO, 2012).

Despite the increasing international recognition of the need to implement strategies and political measures against illicit crops with resources financed by governments, in many countries the results achieved have been scarce (DeBecka et al., 2009; Gootenberg, 2012). For over two decades the US has funded repressive forced coca eradication in Peru, Colombia and Bolivia to reduce the illegal cocaine trade. According to some research (Thoumi, 2002; Lupu, 2004; Peceny and Durnan, 2006; Gootenberg, 2012; Grisaffi and Ledebur, 2016) these policies have never met their stated goals and have generated violence and poverty. Some research argues that the strengthening of the Revolutionary Armed Forces of Colombia (FARC) during the 1990s was an unintended consequence of U.S. antidrug policies (Peceny and Durnan, 2006). As a result, Peru, Colombia and Bolivia suffered a criminalization of coca farmers and failed development initiatives (Grisaffi and Ledebur, 2016). Although these actions have gone through various stages, they have always been characterized by centralized planning models, which have represented the dominant principles of economic development of the 1950s and 1960s (Etzioni, 1968; Lindblom, 1977). These models, along with science and techniques, appear to be infallible tools for the rational development of society based on a common cause which has become known as "modernity" (Cazorla et al., 2013; Philo, 1993). With this same rational focus, actions to solve the drug problem are considered to be inseparable from political power (Schumacher, 1976), based on engineering, scientific reason and a predominantly topdown approach (Bond and Hulme, 1999; Friedmann, 1987, 2005). In 
Peru and Colombia there has been a lack of meaningful consultation with peasants' organizations, poor sequencing of development assistance, a lack of long-term planning and the promotion of crops aimed at the export market, which have proven to be unsuitable as there were often no markets for them (Buxton 2015; UNODC 2005; Grisaffi and Ledebur, 2016.). However, not all policies have been designed from a top-down approach and not all evaluations have been negative, however. The European Union's experience has been very positive in Bolivia; in 2014 the EU Ambassador to Bolivia explained, 'our efforts have been a success; you can also see the impact in the effective and sustained reduction of coca production". The Organization of American States (OAS) cited Bolivia's coca policy (Bolivia's community coca control program) as an example of best practices for implementation and replication; initiatives that enrich dialogue and can inspire each country to understand how it can successfully manage the various challenges posed by drugs within its particular context and economic, political and social circumstances (Briones et al., 2013: 6).

At a geographic level, the drug problem started in the valleys and jungle areas of the Andean region (Dion and Russler, 2008; Moreno et al., 2003). Colombia, Peru and Bolivia are the countries with the largest production of coca and cultivated land, representing nearly 98 percent of the global crop. Despite efforts to eradicate and substitute illicit crops, Colombia continues to be the main producer of coca leaves in the world (UNODC, 2016), with approximately $80 \%$ of the world's cocaine hydrochloride trade coming from rural and indigenous production systems. In recent years cocaine production has increased, going from $442 \mathrm{t}$ in 2015-646 tons in 2016 with approximately 96,000 ha of crops (UNODC, 2016). Other large producers of coca leaves in Latin America include Peru and Bolivia, with approximately 60,000 ha supplying the largest consumption markets in North America and Europe (Vargas, 2005).

The lack of institutional presence in parts of Colombia has led to many regions of the country being less developed. Not only have small farmer settlers taken advantage of this by occupying public lands, but also the illegal armed groups have for producing illicit crops. These armed groups were formed in the 1950s and since the 1970s they expanded and became stronger thanks to the income they received from the trade in illicit crops (Dion and Catherine, 2008). Guerillas and paramilitaries stripped all types of landowners of vast areas of land in Colombia as part of their activities to illegally control strategic areas (Balcázar and Rodriguez, 2013). In the affected areas this process created a breakdown of the social fabric, deterioration of ethical and moral values, family disintegration, lack of trust, land ownership conflicts, an increase in criminal activity and general violence in the rural communities (Bromley, 2008; Perfetti et al., 2013; Holmes et al., 2006).

Another problem caused by the production of illicit crops is environmental damage, as a result of felling and burning forests, and the subsequent depletion of water sources and destruction of biodiversity (Vargas, 2002; Dávalos et al., 2011). Deforestation and land use conflicts were frequent impacts in both conflict and post-conflict countries, and the infectiveness of land use planning were frequent drivers of environmental damages (Suarez et al., 2017). For each hectare of coca or opium poppies, between two and three hectares of forest is destroyed. It is estimated that in a 15-year period, more than 608,000 ha of tropical moist forest have been destroyed (UNODC, 2016). Furthermore, the production of illicit crops is very harmful due to the use of fertilizers, pesticides and chemical products whose residues spill into rivers and are absorbed by the soil (Housego, 2005). Studies (Etter et al., 2006; Armenteras et al., 2006) have also shown that illicit crops and drug trafficking directly cause deforestation due to the construction of infrastructure such as illegal runways and roads, as well indirectly through the privatization of public land to create "narco ranches". Therefore, coca crops continue to pose a threat for biological and cultural diversity in Colombia (UNODC, 2016), limiting the large potential for growth in agriculture and in the rural economy (Norton and Balcázar, 2003). But according to other research, the geography of place plays an important role in determining deforestation rates (Suarez et al., 2017). In opposition to the previous research, some studies in Bolivia (Bradley and Millington, 2008) provides weak support for the argument that low deforestation rates are typical of a coca regime and stronger support that after coca is abandoned, deforestation rates increase due to farmers would clear large areas of forest after abandoning coca to maintain household incomes. Internationally financed eradication campaigns force traffickers and growers to constantly relocate, making drug-related activities a principal cause of forest loss (Fjeldså et al., 2005).

These processes of expanding illicit crops in Colombia have coincided with the implementation of plans supported by the United States for eradicating coca and destroying the cartels who export out of Colombia (Coletta, 2005). Although these intervention methods have been applied in Colombia for many years, the problem still exists. At a national level, the Colombian Government has promoted various policies and programs for fighting the production of illicit crops and creating new legitimate employment and income opportunities for the rural communities (Moreno et al., 2003; Balcázar and Rodríguez, 2013). The Government's first programs for fighting illicit crops were "Campo en Acción" (1990-1994) and "Plante y 'Pa-lante' (1994-1998). Based on the experiences with the previous programs, there was a move towards a phase in which integrated strategies were adopted involving bilateral cooperation between the Governments of Colombia and the United States of America. This led to the implementation of "Plan Colombia" in 1999. This agreement emphasized the international responsibility for the fight against drugs (Veillette, 2005).

These programs from the Colombian Government were designed based on the "International Conventions on Narcotic Drugs", 1961, 1971 and 1988, and were known as Alternative Development (Mansfield, 1999; Balcázar, 2008). As a result, Alternative Development became a policy for fighting illicit crops, initially promoted and executed with international cooperation, especially through the United States Agency for International Development (USAID) programs. A particular emphasis is placed on economic aspects to promote the substitution of illicit crops for legitimate ones (Vargas, 2005) and its impact is primarily measured by the evolution of eradicated hectares (Moreno et al., 2003). Fig. 1 shows the change in cultivated land, according to the latest report from the United Nations Office on Drugs and Crime (UNODC); although there has been a decline since 2001, the strategy has stalled in the last three years, and since 2013 the total area of illicit crops has increased to 96,084 ha by 2015 . Whilst 'alternative development' approaches have changed over the years, however, with few exceptions, these programs have not offered poor farmers realistic alternatives to growing coca (Farthing and Kohl, 2005; Mansfield 2011; Buxton 2015; Grisaffi and Ledebur, 2016).

Although this alternative development policy in Colombia has had significant changes of direction (Mansfield, 1999; Ortiz, 2003; Balcázar, 2008), all of these eradication programs have been promoted and managed by the National Government, in line with a classic model of so-called Social Reform (Friedmann, 1987). Its actions are characterized by their "bottom-up" approach, with a technical vision and actions designed by planners in the public sector and program directors (Ávila Cerón and De los Ríos-Carmenado, 2017). The results have generally

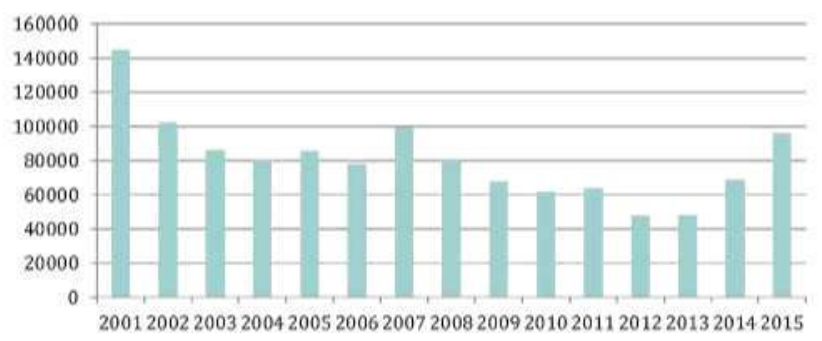

Fig. 1. Evolution of coca crops in Colombia (hectare/year). 


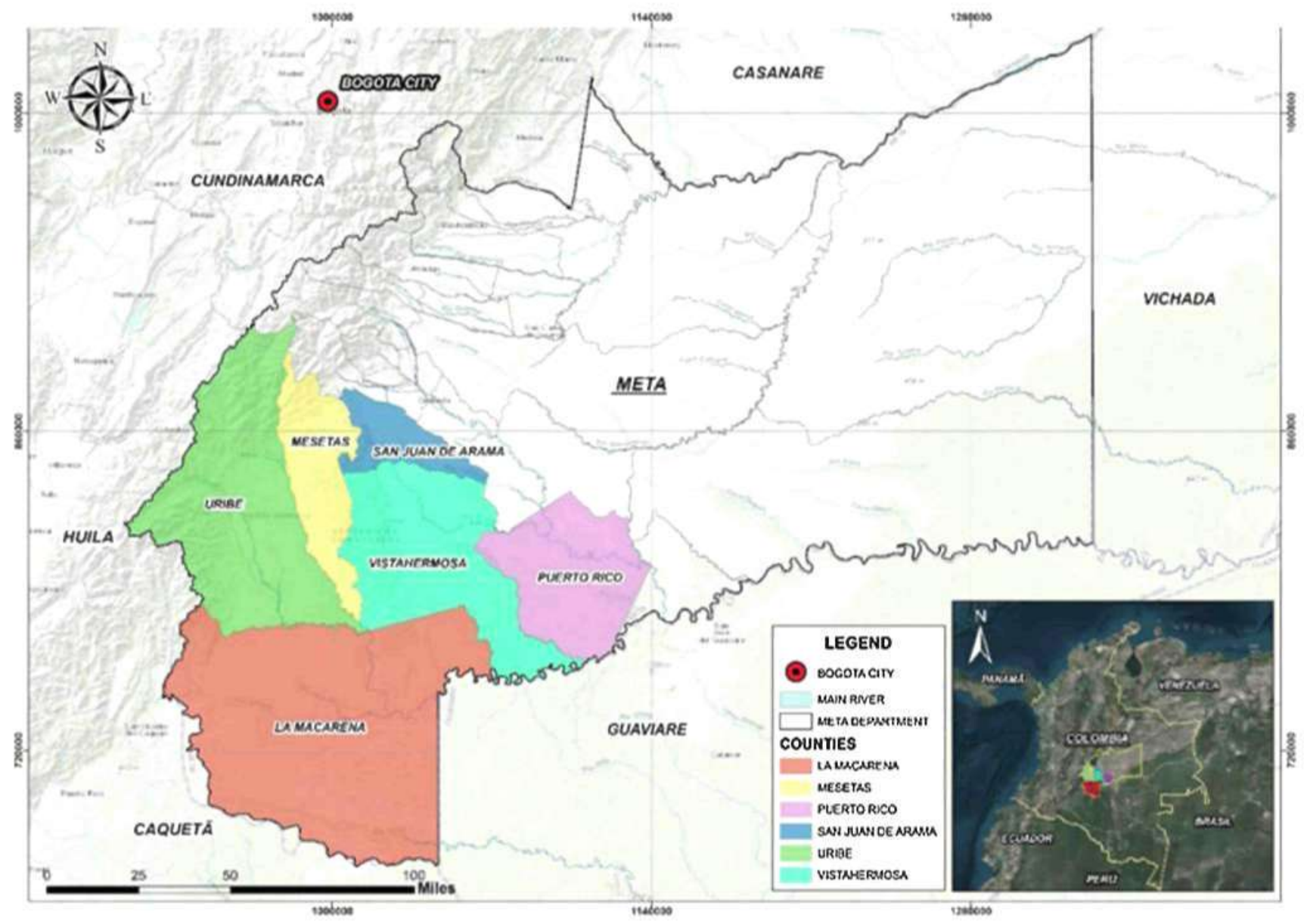

Fig. 2. Project area: Macarena Region.

been technical projects with a production focus, aimed at creating new incomes for the population through the substitution of an illegal economy for a legal one. Very few projects have focused on building trust between the population and the State as a basis for rural development (Pérez Correa, 1998; Vargas, 2002). Furthermore, despite the short-term reduction in the cultivated area, the key question regarding the sustainability of these results remains unanswered.

Some studies have evaluated the effectiveness of the Alternative Development programs (Moreno et al., 2003; Vargas, 2005; Ávila Cerón et al., 2016), questioning the lack of results compared to the efforts carried out. The main weaknesses are linked to the planning model that was implemented, which sought to resolve problems from a "technical perspective" (Friedmann, 1987), with actions that were very isolated from the reality facing rural societies (Vargas, 2005). In many cases they lacked the involvement of the affected population in terms of designing measures. Although these "technical models" based on scientific planning have traditionally been applied when implementing projects which have been planned from the top-down, they face a crisis (Bond and Hulme, 1999; Philo, 1993; Ostrom, 1998), as new planning models have arisen in postmodernity which aim to connect knowledge with action (Cazorla et al., 2013). Furthermore, the Colombian Government has recently emphasized the need to find new models (UNOCD, 2016), which can lead to an understanding of the complexities relating to the drugs phenomenon through individuals in the affected areas, and from a broad perspective within a framework of respect for human rights and sustainable development.

Through this search for new strategies and review of existing ones, this study analyzes the results of implementing an alternative development experience, under a "Working with People" focus (Cazorla et al., 2013) in the armed conflict area of La Macarena. This proposal extends further than a traditional technical-economic vision, and aims to influence individuals' behavior in terms of activities and projects implemented, through dialogue with the communities affected by illicit crops. The proposal is based on creating rural prosperity from the perspective of the relationship between the global drugs problem and sustainable development (UNOCD, 2016), through the links between social development, economic development, environmental sustainability, the quest for non-violent, fair and inclusive societies, and the creation of alliances.

\section{Case study: 50 years of armed conflict in La macarena region}

The region of La Macarena was chosen for this study. It is located to the south of the State of Meta, and is formed of six municipalities (San Juan de Arama, La Macarena, Mesetas, Puerto Rico, Uribe \& Vista Hermosa) covering 29,837 square kilometers with a population of approximately 100,000 inhabitants (DANE, 2015). These are areas of great environmental and strategic importance, with high potential for social and economic development. The geographic area, which forms this case study, lies between the Andean region and Orinoco-Amazonia, between the eastern and western sides of the La Macarena mountain range, including the municipalities of Mesetas. This is a large jungle area formed of three national parks (Sierra de la Macarena, Tinigua, Cordillera Picachos and part of Sumapaz), with more than 14,000 square kilometers of protected areas.

The State's limited presence and the armed conflict have led to La Macarena region being historically characterized by the high level of illicit crop production, and based on the latest official figures (UNODC, $2016)$, there are 5,002 ha of coca in the region $(5.21 \%$ of all coca that is produced in Colombia). Furthermore, the illegal armed groups are 
using this area for transporting and selling narcotics, causing the rural communities to be isolated and unable to integrate with the socioeconomic dynamics of the rest of the country. This means that the coverage and quality of services such as education, health and security is well below the national average. The average rate of Unsatisfied Basic Needs (NBI) in La Macarena region is $73.77 \%$, compared with a national average of $36.6 \%$ (DANE, 2015).

The region was selected for this study as it has the following characteristics: 1) social learning processes are being promoted between producers, companies, civil society bodies and local, regional and national governments under the framework of the "Plan de Consolidación Integral de la Macarena (PCIM)"; 2) the Plan is considered as a successful example with a socioeconomic objective, recognized in various forums; 3 ) there is an innovative strategy with public-private links for implementing production projects aimed at substituting illicit crops; 4) it is of particular environmental and ecological interest, with a vast jungle territory made up of three natural national parks; 5) there is cultural diversity with indigenous settlements recognized under three safeguards (Plans in Uribe, Ondas del Cafre \& Villa Lucia in Mesetas); 6) it incorporates a historic process of over 50 years of armed conflict with the illegal groups and illegal activities linked to producing and selling cocaine in Colombia. The phases of this alternative development policy in Colombia (1964-2016) are summarizes below, which the region has been through. It covers the different historic milestones and events that have occurred in relation to Alternative Development policies in Colombia (Fig. 2).

a) Establishment of illegal armed groups in La Macarena (1964-1980)

The armed conflict started in 1964, when the illegal armed groups (IAG), and in particular the FARC, established themselves in La Macarena due to the strategic value of this area in terms of their illegal activity as well as for producing and selling cocaine (Holmes et al., 2006). The jungle characteristics, poor access roads and informality of rural land ownership (Salas, 2010) made the area a logistic and operational epicenter for illegal activity and illegal enlistment (of children and teenagers). This presence of IAGs would have a historic and symbolic prevalence, with the presence of the most active and strongest military groups (Reyes, 2008).

b) Empowerment and self-financing of the IAGs through drug trafficking (1980-1997)

During the 1980s and 1990s, the FARC-EP pursues ongoing illegal military activity, becoming an independent and autonomous actor. In the 1980 s the IAGs established alliances with drug cartels, creating a logistic chain, controlling illicit crops and continuing with the conflict. During this decade, there were extensive land evictions and forced displacements of families as a result of the illegal activities. In the 1990s, the FARC-EP gained control of the entire drug trafficking in the region, they restricted local administrations and continued to strip the land and displace families. In collaboration with specialist criminal groups, the IAGs were able to become self-financing through drug trafficking, accessing markets in Europe and the United States. This selffinancing allowed them to provide farmers in the region and traffickers involved in the trade with basic services, such as law and order, as well as protection against the army and police operations. In exchange for these services, the FARC collected payments through a "revolutionary tax" which was charged to farm owners, business owners and professionals (Ortiz, 2003).

c) Plan Colombia (1997-2015): Alternative Development Policy phases

Due to the scale of the armed conflict, Plan Colombia was established in 1997 as an institutional framework of bilateral cooperation between the governments of the United States and Colombia. The objectives of this alternative development policy were to: i) strengthen the operational capability of the Public Forces against drug trafficking and the fight against the Illegal Armed Groups; ii) implement a protection and social support strategy to strengthen Colombians' economic and social conditions; and iii) support disarmament processes in Colombia. Plan Colombia lasted 15 years, in three phases which were co-financed between both governments: 9660 million from the United States and 131,000 million dollars from the Colombian Government.

d) Start of a pilot project in La Macarena region: Demilitarized zone (1998-2002)

In 1998 a pilot project began in La Macarena called the "Demilitarized Zone". The objective was to find an intervention model to end the armed conflict in Colombia through dialogue with the FARCEP and by "working with people". This demilitarized zone is located in an area of $42,000 \mathrm{Km} 2$, which includes the towns of Vista Hermosa, Uribe, La Macarena \& Puerto Rico. The FARC-EP exerted their control in this area by displacing the population as well as State Institutions (Echandia, 2011). As a result of the FARC's territorial control, a climate of distrust and fear arose amongst the population and external actors. This also led to a weakening of local governments, lack of legitimate land ownership rights, a decline in infrastructure and basic social services, intensive use of land and natural resources (Wilson, 2002). The region was also chosen for its strategic location in the center of the country, forming a competitive corridor, with large gas and oil reserves and high environmental value (Balcâzar, 2008).

e) Restoring Territorial Control (2003-2006): first phase of Plan Colombia

In 2003 the armed forces, with the support of the United States, launched the Patriot Plan to restore control of the jungle. Military action (Operation 'Colombia Verde') began with the objective of eradicating the illicit crops and weakening the FARC-EP's military structure. These actions were implemented during the first phase of Plan Colombia, which was called Plan for peace, prosperity and strengthening the State. The objectives were to strengthen the Public Forces' capabilities, eradicate illicit crops, support alternative development, as well as economic and justice objectives in the regions affected by the armed conflict. In the first three years of Plan Colombia, 3200 million dollars were invested which led to a reduction in illicit crops from 140,000 to 113,000 . Plan Colombia had a counterinsurgent focus. The fight against drugs and counterinsurgency were controlled under a collaboration that remains in place today. At the start of 2004, the armed forces, with the support of the United States South Command, launched an ambitious counterinsurgency plan called "Patriot Plan", with the aim of restoring territorial control of the vast jungle, which was at the mercy of the FARC-EP. Professional troops were deployed in Caguán, Guaviare and Meta, who were well equipped with advanced technology. During the first two years of military presence and crop spraying, the focus was on tackling the illicit crops in La Macarena, which had increased from 9,222 ha of coca in 2002-17,305 in 2005. In the National Park of La Macarena, by December 31 st 2005 the planted area was 3,354 ha, made up of plots smaller than 3 ha. This represents an increase of $24 \%$ compared to the previous year. In terms of the effectiveness of the 'Colombia Verde' military operation for eradicating crops and hitting the FARC-EP's finances in order to weaken its structure, the results raise many doubts.

f) Plan de Consolidación Integral de la Macarena, PCIM (2007-2012)

This plan formed part of the second phase of Plan Colombia: Strategy for strengthening democracy and social development (2007-2009) and the start of the third phase: Strategic development initiative for Colombia (2010-2015). During the second phase of Plan Colombia the fight against terrorism and drug trafficking continued, as well as efforts to strengthen justice and promote social and economic development, especially amongst the displaced population. This culminated in the third phase of Plan Colombia, achieving results such as the elimination of 45,000 ha of coca per year (Ortiz, 2003). In terms of the consolidation process in La Macarena, this involved key actors such as the Community Action Committee, Municipal and Regional Administrations, Financial institutions, the Ministry of Mines \& Energy, Agriculture \& Rural Development, Defense and Transport, as well as the 


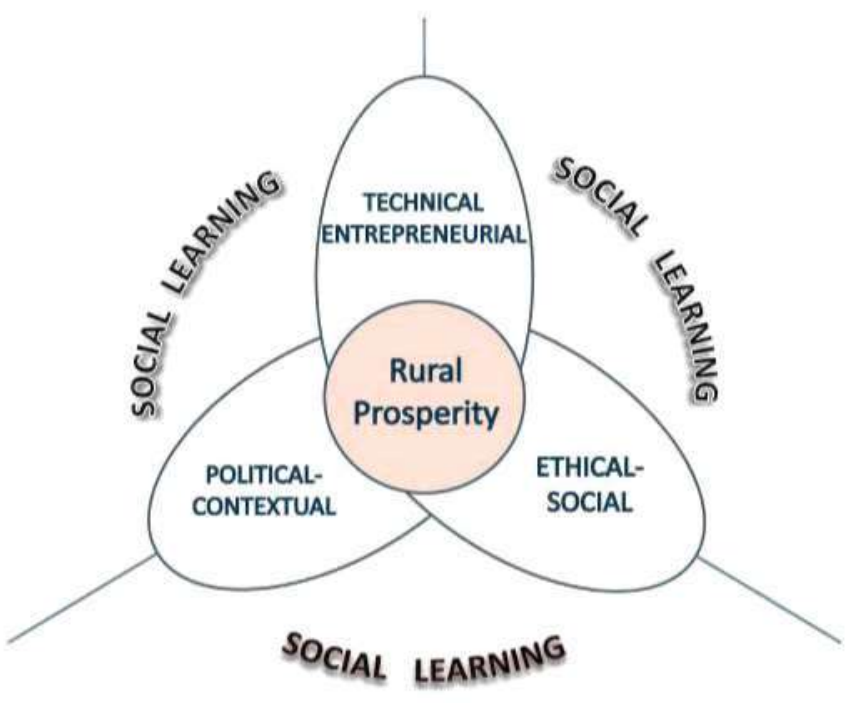

Fig. 3. Rural prosperity dimensions based on the WWP model.

State's Security Services and international cooperation. Despite the advances in territorial security and the Public Force's strikes on high value objectives (Echandía, 2011), which enabled large areas to be incorporated in the regional development (Reyes, 2008), there was still an armed presence from the FARC in large jungle areas, which represented the main threat for consolidating territorial security. These attracted a large number of poor individuals and families, creating a new subversive and illegal support network (Franco, 2010). As a result of this, any State action to recover land required increased efforts in terms of war tactics and strategies in the sensitive and necessary context of respecting human rights (Serra, 2010), as well as a forceful campaign towards freedom of participation, values and principles so that the population became involved in territorial development processes.

g) Signing of the Peace Accord between the Colombian Government and the FARC-EP Guerilla Group (2012-2016)

During August 2013, in Habana Cuba, representatives from the National Government and delegates from the FARC signed the General Agreement for the Termination of the Conflict and the Construction of a Stable and Lasting Peace (Decree 2003 of 2016). The process involved three phases: i) exploratory (February - August 2012), which resulted in the signing of the General Agreement for the Termination of the Conflict and the Construction of a Stable and Lasting Peace; ii) Roundtable discussions (October 2012 to November 2016); iii) phase for constructing peace or post-agreement, which started with the signing of the final agreement. The objective of this process was to end the armed conflict, eliminate the conditions, which have allowed the conflict to take place over time, and guarantee Colombians' rights. Subsequently, the current Government (2014-2018) and the Revolutionary Armed Forces of Colombia (FARC-EP) signed a Peace Accord for the Termination of the Conflict and the Construction of a Stable and Lasting Peace on November 24th, 2016. The Peace Accord contains six key points: 1) Comprehensive Rural Reforms, 2) Political participation: an open democracy for constructing peace, 3) Bilateral and definitive ceasefire and laying down arms, 4) Solution to the illegal drugs problem, 5) Victims, and 6) Implementation and verification mechanisms. The Peace Accord includes pillars and objectives for constructing sustainable peace, eliminating illicit crops and laying the foundations for the country's social and economic development over the next 15 years $(O A C P, 2016)$ in areas affected by the armed conflict.

h) The beginning of the end of the conflict

The Final Agreement for the Termination of the Conflict and the Construction of a Stable and Lasting Peace, signed in November 2016, came into power following its endorsement by the Colombian Congress. Some of the first actions are those linked to the process of abandoning arms, legal transition and reincorporating the FARC-EP and its members into civilian life. Abandoning arms and legal transitions started in January 2017 across the 20 "Transitory Rural Settlement Normalization Zones" (ZVTN) and 7 "Transitory Normalization Points" (PTN) previously agreed between the Government and FARC-EP negotiation teams. In the region of La Macarena, three ZVTNs were established (in the towns of Vistahermosa, Mesetas \& La Macarena). This process would be monitored and verified by the Tripartite Monitoring and Verification Mechanism (MM\&V) which was also responsible for en suring compliance with the Bilateral \& Definite Ceasefire (CFHBD). Specifically, the United Nations would be responsible for receiving all the weapons, as an international component of the Mechanism.

\section{Material \& methods}

The methodological framework applied is based on the Working with People (WWP) model (Cazorla et al., 2013), which is the result of 25 years of experience in projects aimed at improving the prosperity of rural zones in the European context and in emerging countries. It also incorporates new trends and values linked to prosperity. This extends further than merely accumulating wealth, by focusing on individuals' capabilities in order to improve the quality of life (Legatum Institute, 2013; Sardar, 2007; Rapp, 2008; SDC, 2009). It is based on a comprehensive focus, which is centered on the individual (Jackson and Anderson, 2009; Cazorla et al., 2013; De los Ríos et al., 2016a,b) and social wellbeing (Kasser, 2007; Midgley, 1995). The model incorporates social learning processes in order to analyze and develop rural prosperity in vulnerable and socially complex rural zones, through the three dimensions shown in Fig. 3.

The ethical-social dimension considers the context of behaviors, attitudes and values of the people that are involved in development processes (production, transformation and commercialization). The technical-entrepreneurial dimension is focused on the creation of products and services for society through quality standards and with differentiating elements in the market. The political-contextual dimension enables communities and organizations to adapt their priorities and projects in the contexts in which they operate, in order to achieve success through sustainable management. Finally, the dimension that integrates the three other dimensions is social learning (Cazorla et al., 2013). Based on this methodological framework, different tools and sources of information are incorporated. On one hand, the compilation and review of numerous secondary sources (scientific literature and historic information from the Transition Plans). On the other hand, the study includes empirical information obtained through interviews with the key agents in the region of La Macarena. In order to gather and systemize the expert knowledge, participative processes with a WWP focus were used.

\subsection{Data collection: tools and protocols}

Firstly, in-depth direct interviews were carried out. A semi-structured interviews around a list of questions were designed based on a jointly developed conceptual and analytical framework (Darnhofer et al., 2014) carried out in the international Rethink research program. This program studied links between prosperity and rural development. The semi-structured interviews were designed and validated by a panel of experts from 14 countries, formed a multi-sector and interdisciplinary panel of Rethink Ruragri ERA-NET (Rivera et al., 2017). They have a holistic approach (De los Ríos-Carmenado et al., 2013; Legatum Institute, 2013; Sardar, 2007; Rapp, 2008; SDC, 2009), based on the "Working with People" framework (Cazorla et al., 2013). These semi-structured interviews designed proposed questions to elicit the interviewee's ideas and opinions on the rural prosperity topics.

The semi-structured interviews divided the questions into the dimensions of the WWP framework: the first question was aimed at understanding the influence of the political-contextual dimension on 
prosperity; a second set of questions related to the ethical-social dimension of prosperity; and a third set on the technical-entrepreneurial dimension of prosperity. The interviews were conducted individually and face to face with the families of the La Macarena Community who have benefited from the PCIM's program and have been involved in its management. The interviews were carefully planned, focusing on developing rapport and establishing a relaxed, comfortable climate. In the first place, providing an overview of the purpose, a few background questions such as the interviewee's job, productive activities, about the family, etc. Immediately after the interview, the interviewer completed his notes and wrote down your impressions.

The social base consists of 2503 families (with 4 or 5 members) in the area known as La Serrania de la Macarena. 250 families, which were representative of the municipalities, were selected $(10 \%$ of the 2503 target families) and 46 families were interviewed (randomly selected and representative of the municipalities), obtaining a response of $18 \%$ (46 owners), which is statistically acceptable and did not require an increase in the sample size.

For the expert knowledge, the project management report of the Management Body of Colombia was used, an entity responsible for the management of PCIM. This high response from members of the Community is a guarantee of interest in the PCIM. A second tool with a different focus group (workshop) was held as part of the Project Management activities and monitoring of PCIM, including the Program Director and applying the same questionnaire criteria.

The fieldwork as a whole was carried out between March and December 2016 by the project's research team. The people selected as part of this process are part of a social learning process spanning more than 20 years, including the expert knowledge of producers, civil society agents and local, regional and national governments in the region; especially those involved in projects that are being implemented to eradicate illicit crops in the region of La Macarena. For the treatment of data, we used the statistical program SPSS V.19. Finally, the integration of results - experienced knowledge of the affected population with expert knowledge- allowed lessons to be drawn and appropriate actions to be taken.

\section{Results and discussion}

This section analyzes the different dimensions on which the methodological focus is based, incorporating expert knowledge, for implementing projects aimed at substituting illicit crops and creating rural prosperity in armed conflict areas. The results generated from the application of the stated methodology are presented in a logical structure, based on the three dimensions of the WWP model.

\subsection{Influence of the social relations system's scope}

Through the model, actions have been created for substituting illicit crops and creating rural prosperity in armed conflict areas. Agents from different areas of the social relations system have carried out these actions. The processes observed highlight the public-administrative field $(42.8 \%)$ and civil society $(25.1 \%)$ as having the greatest influence on generating rural prosperity; and to a lesser extent, agents from the political area $(16.3 \%)$ and business sector $(15.9 \%)$. As shown in other studies (Jackson and Anderson, 2009; De los Ríos et al 2016a,b; Knickel, 2016; Šũmanea et al., 2017), the interaction between agents from different sectors helps to create trust and establish a social network for integrating learnings from the rural areas' population.

In terms of the public-administrative sector (42.8\%) the Unit for Territorial Consolidation (UACT) under the National Government's Department for Social Prosperity stands out. The UACT's mission is to promote the private sector in the State's institutional presence, as well as international cooperation in order to consolidate and rebuild territories and establish trust among the population of the affected areas. Its objective is to coordinate and manage the implementation of the
National Policy for Territorial Consolidation and Reconstruction, and the National Policy for the Manual Eradication of Illicit Crops and Alternative Development. Another relevant agent from the public-administrative sector is the National Learning Service (SENA) run by the Ministry of Labor in Colombia, as it teaches young people and develops competences for improving competitiveness amongst producers and companies; the Ministry of the Environment's Regional Autonomous Corporation CORMACARENA carries out activities to promote sustainable development and biodiversity conservation in the National Parks.

In the civil society sector $(25.1 \%)$ the Colombia Responds platform stands out for its efforts to establish public-private alliances in the program's intervention areas. Furthermore, the 'Prodepaz' Network and the Communal Action Councils have been able to coordinate roundtable discussions relating to local development and building peace in the area between civil society, the government, companies, the church, and international cooperation.

In terms of the private-business sector $(15.9 \%)$ the Provincial Center for Agribusiness Management (CPGA) stands out for establishing an alliance for providing technical support services and strengthening production chains with an agribusiness focus. Higher education organizations, especially the University of los Llanos located in the State of Meta, have also had an influence on the region of La Macarena, improving professional competences in order to respond to farming and livestock expansion. Table 1 summarizes the total scores for each of the WWP model's dimensions in terms of the impact they have had on the substitution of illicit crops, territorial reconstruction, and creation of rural prosperity in La Macarena region. The following sections show the results achieved through the three dimensions of the WWP model.

\subsection{Political-contextual component: towards a new planning model for alternative development}

The most highly scored dimension is Political-contextual $(40.92 \%)$, as the main challenge is to ensure all the actors create a new planning and implementation model for the National Policy for Territorial Consolidation and Reconstruction, as well as the National Policy for the Manual Eradication of Illicit Crops and Alternative Development. Through this component, there has been a new focus in La Macarena with regards to Alternative Development Policy planning processes, as a pilot for creating prosperity and implementing the peace process. As stated by a community leader: "in the face of the FARC's violence, we have won the war in Colombia without firing a single shot" (Community Leader). The actions have sought to establish new relationships between the governments, the various public administrations, the Illegal Armed Groups and the affected population.

This ability to create relationships is based on setting up an internal organization (Argyris and Schön, 1978; Senge et al., 1999), which incorporates social learning processes in order to implement actions (Cazorla and De los Ríos, 2017) through a new planning model. These organizations are known as Post Conflict Agencies and are part of the Administrative Unit for Territorial Consolidation's (UACT) remit; facilitating participation and the creation of social dynamics. Through these organizations, the objective is to ensure there are organizational changes in the Alternative Development policies, which enable

Table 1

Influence of the WWP dimensions on territorial reconstruction and creating prosperity.

Source: Own elaboration from fieldwork.

\begin{tabular}{ll}
\hline WWP Dimension & Total Score \\
\hline Political-contextual & $40.92 \%$ \\
Ethical-social & $31.27 \%$ \\
Technical-entrepreneurial & $27.36 \%$ \\
\hline
\end{tabular}


Table 2

Baseline in La Macarena Region.

Source: UACT 2014

\begin{tabular}{|c|c|c|c|c|c|}
\hline TOWN & Area $(\mathrm{Km} 2)$ & Urban Population & Rural Population & Total Population & Population Density (Inhabitants/Km2) \\
\hline Vista Hermosa & 4.084 & 6340 & 14.854 & 21.194 & 5,19 \\
\hline Uribe & 7.640 & 2754 & 9963 & 12.717 & 1.98 \\
\hline Puerto Rico & 3.431 & 5.162 & 12.924 & 18.086 & 5.27 \\
\hline La Macarena & 11.229 & 4056 & 22984 & 27.040 & 2.15 \\
\hline Mesetas & 2.448 & 3.253 & 7.655 & 10.908 & 4.45 \\
\hline S. J. De Arama & 1.163 & 3446 & 5726 & 9.172 & 7,89 \\
\hline TOTAL & 18.924 & 25.011 & 74.106 & 99.117 & \\
\hline
\end{tabular}

measures to be implemented in response to the priorities of the affected people, working with actors from the political area as well as those from the public administration. Based on this new Alternative Development focus, these organizations play an instrumental role in serving the population, whilst being flexible and adapting to the learnings (Habermas, 1996). Decision-making is carried out during roundtable discussions, with agents from different social relations subsystems, including civil society and the private sector. This involves creating spaces for collective deliberation, with regular meetings involving different actors from civil society, public entities, business organizations, agents from international collaborations and universities, in order to find solutions to the problems being faced. Therefore, the project organization becomes a "living entity", which also transfers values to society (through its ethical component) and is capable of influencing and changing political priorities and working collaboratively (Cazorla et al., 2013). As stated by one of the Mayors from the area: "the successful aspect of the model is the inter-institutional articulation between different agents and public and private bodies" (Local Government Mayor) (Table 2).

This planning process for implementing Development policies in the region of La Macarena includes four phases. From the offset, it aims to achieve social integration and participation from the families in the illicit crop eradication zones. The first phase involved territorial delimitation of the illicit crop eradication zone, identifying the núcleos veredales $^{1}$ as a joint agreement with the population, municipal and military authorities. These rural district groups (Núcleos de Veredales) share similar characteristics (socio-economic, political and environmental), enabling a territorial focus in the implementation of the alternative development model, and facilitating working with people (Philo, 1993; De los Ríos et al., 2011a). Subsequently, a baseline is created by quickly assessing the territory's socioeconomic characteristics. To achieve this, direct surveys were carried out with the inhabitants and official reports from the UNODC's Illicit Crop Information Systems were used, as well as Territorial Planning Schedules for each municipality.

During the second phase, the Transition Plan was created as a Rural Development tool with a territorial focus. As part of this phase, "working with people" continued with the rural district groups, municipal, national and international governments. The principles applied by the LEADER initiative, using a planning model based on social learning and training at a local level (Cazorla et al., 2005; De los Ríos et al., 2011a) are the basis for this process of constructing the Transition Plan. The Plan's strategic points included aspects relating to food security for families, production projects, technical and social support, improving social infrastructure and support for young people and women. During this phase, agreements were made through the numerous district meetings in local communities as well as workshops, in order to identify, prioritize and co-create projects. An innovative

\footnotetext{
${ }^{1}$ Vereda is a term used in Colombia to define a type of geographical area in different municipalities across the country. Veredas are mainly comprised of rural areas, although they sometimes contain a small urban center. A vereda usually has between 50 and 1200 inhabitants, although this can vary in some cases depending on the location and geographic density.
}

approach to projects was sought in order to solve rural problems. Similar to other programs (Cazorla et al., 2005; Knickel, 2016), innovation in order to find new solutions was focused on diversification and creating multi-sector and multifunctional links. A cohesive focus was another key aspect of the model, as it created links between the development actions (Cazorla et al., 2005). This phase culminated in a document agreed with the community, in which prioritized projects were identified, such as the start of the Transition Plan. Another of the Local Governments stated: "we as Local Governments are conscious that we have an important commitment and responsibility for implementing the projects identified in our communities" (Local Government).

The third phase involved the presentation, negotiation and signing of the Transition Plan. In order to do this, representatives from the rural district groups (Núcleos veredales), along with the technical team, presented the Transition Plan and its projects to the inhabitants and municipal governments. During this negotiation phase, the main purpose was to create public-private associations in order to implement alternative development projects, thus marking the beginning of a new collaborative relationship based on mutual trust (Naoum, 2003). These alliances have demonstrated many positive aspects, creating publicprivate synergies (McQuaid, 2002), developing project management competences (Sastre-Merino and De los Ríos, 2002) and overcoming social complexities (De los Ríos-Carmenado et al., 2013; De los Ríos et al.,2014) in the development processes. A leader from a Community Association in one of the towns argued: "... we have to join forces and create alliances in order to finance government projects" (Community leader). Following a negotiation process between the various actors, this phase culminated in the signing of the agreements for implementing the Transition Plan.

In the last phase, the Transition Plans were implemented, monitored and evaluated. During this phase, the government team's work was limited to technical consultation with the promoters. They removed themselves from the decision making process in order to ensure proper ownership of projects among the inhabitants and families. As stated by another Community Leader: "...The projects have been set up and they have been carried out according to what we agreed at the start of the Plan..." (Community leader). As has been the case in numerous other experiences and development models (Cernea, 1991; Bond and Hulme, 1999), this bottom-up approach is a key element for ensuring all the local agents are involved and supportive in order to guarantee the projects' success. This also avoids a dependency on the government, enabling the families and rural population to take ownership for decisions (Stratta et al., 2017). In Table A1 in Appendix A, the Technical-entrepreneurial Projects implemented during this phase are detailed.

\subsection{Ethical-social component: rebuilding trust}

Secondly, the ethical-social dimension is scored (with an overall score of $31.27 \%$ ). This includes actions for creating trust in order to work in teams. The FARC-EP and drug trafficking exerted their dominance on the social, political and economic system in the region of La Macarena, displacing the State's institutionality (Echandía, 2011) and causing disputes relating to territorial power in neighboring towns 
Table 3

Ethical-Social Dimension Strategies.

Source: Own elaboration from fieldwork (Ávila Cerón et al.. 2016). (Note that answers are neither inclusive nor exclusive).

\begin{tabular}{|c|c|c|c|c|}
\hline \multirow[t]{2}{*}{ Ethical-social Dimension Effects } & \multicolumn{4}{|c|}{ Level of influence } \\
\hline & 1 Very weak & 2 weak & 3 strong & 1 Very strong \\
\hline Improvements in information and knowledge & $0 \%$ & $0 \%$ & $10 \%$ & $90 \%$ \\
\hline Open attitude towards cooperation and collaborative working & $0 \%$ & $0 \%$ & $15 \%$ & $85 \%$ \\
\hline Murual learning and knowledge exchange & $0 \%$ & $0 \%$ & $18 \%$ & $82 \%$ \\
\hline Development of personal and community values & $0 \%$ & $0 \%$ & $25 \%$ & $75 \%$ \\
\hline Ability to overcome conflicts and crises & $0 \%$ & $0 \%$ & $30 \%$ & $70 \%$ \\
\hline Development of skills and competences & $0 \%$ & $10 \%$ & $20 \%$ & $70 \%$ \\
\hline Leadership development in rural communities & $0 \%$ & $13 \%$ & $25 \%$ & $62 \%$ \\
\hline A sense of belonging amongst actors involved & $0 \%$ & $15 \%$ & $25 \%$ & $60 \%$ \\
\hline Autonomy in terms of decision making & $0 \%$ & $28 \%$ & $14 \%$ & $58 \%$ \\
\hline Improved local governance and democratic processes & $0 \%$ & $20 \%$ & $35 \%$ & $45 \%$ \\
\hline Establishing trust between people & $0 \%$ & $32 \%$ & $30 \%$ & $38 \%$ \\
\hline Respect for social values & $0 \%$ & $25 \%$ & $40 \%$ & $35 \%$ \\
\hline Ability to negotiate between key actors & $10 \%$ & $40 \%$ & $15 \%$ & $30 \%$ \\
\hline Increased diversity in the community & $25 \%$ & $55 \%$ & $20 \%$ & $0 \%$ \\
\hline Improved environmental protection through people & $40 \%$ & $40 \%$ & $20 \%$ & $0 \%$ \\
\hline Equal opportunities for everyone & $50 \%$ & $50 \%$ & $0 \%$ & $0 \%$ \\
\hline
\end{tabular}

(Clemencia et al., 2005). This situation created a climate of distrust and fear amongst the population and a lack of empowerment in local governments (Wilson, 2002). With the model, “...rule of law is established and new legal crops are produced" (Regional Government Leader).

The inhabitants who were interviewed argued that, since 2012, there has been a radical change thanks to the Post Conflict Agencies, “... giving people ownership in the implementation of policies, creating trust amongst the community and providing immediate solutions to people's needs...previously here the owners of the farms weren't in charge, the illegal armed groups were..." (Community Leader). These territorial agencies, managed by the Administrative Unit for Territorial Consolidation (UACT), have facilitated participation and the creation of social dynamics in order to create trust and values, laying the foundations for collaboration and teamwork. The UACT's mission is to promote collaboration for consolidating and reconstructing territories and build trust amongst citizens in the affected areas (UACT, 2017). These values are also included in the Learning Network's mission as "a community of change where it is necessary to work based on people's abilities, skills and experiences, making way for different models that can create new types of relations" (UACT, Learning Network, 2017). As a result, based on a technical and economic vision of prosperity (Kasser, 2007), the new planning model seeks to create a new culture for reconstructing the affected territories, incorporating and promoting training, values and ethics in order to improve trust among citizens. With the participation actions carried out, the aim is not just to consult people, it also involves the idea of collective action (Cernea, 1991) aimed at reconstructing social capital and creating participative local government structures. The experience of the Local Action Groups (LAG) from the LEADER rural development model in the European Union (EU) has helped to define similar structures in other contexts; developing leadership skills (De los Ríos et al., 2011b; Stratta et al., 2017; Sastre-Merino and De los Ríos, 2002) and building trust. This recovery of trust is achieved by "Working with people" emphasizing the development of skills and requiring planners to maintain social sensitivity and be ethical (Cazorla et al., 2013).

In accordance with the learning and understanding of the key agents interviewed, the elements of the ethical-social dimension which have had the greatest influence in terms of this new Alternative Development model are shown in Table 5. These results provide an understanding of the underlying values and beliefs of the people involved, as well as their vision of rural prosperity in post conflict areas.

The improvement of information and knowledge primarily stands out in terms of factors linked to the production of alternative crops, production techniques and other aspects which farmers believe are important to achieve rural prosperity. Farmers believe that improving their knowledge and sharing information with the community are fundamental to work in solidarity (Community producer).

An open attitude towards cooperation and collaborative working is another of the most highly scored aspects; one of the historic characteristics linked to coca production is the isolation of families from their communities, primarily due to the risk and fear of acting illegally and their commercial relationship with the illegal armed groups who become stronger as a result of the commercialization of illicit crops (Community Leader). The change from this production model has facilitated a more open attitude towards cooperation, developing farmers' skills through collaborative working. When we talk about illicit crop substitution processes we are basically talking about a process to rebuild democracy (Regional Government Mayor).

As a result of the above, there has been mutual learning and knowledge exchange, enabling farmers and families to come together through their civil organizations, primarily Community Action Groups and Associations of Producers. This union has promoted a strong sense of belonging between actors from the territory and increased trust in the State. This sense of belonging and social interactions are linked to an improvement in rural prosperity (Van der Ploeg et al., 2008).

The development of personal values and community values has become a strategic aspect for rural prosperity and the substitution of illicit crops. The inhabitants consider that the Transition Plans have strengthened social cohabitation, bonds, and collaboration with communal projects, with behavior that is respectful towards others (Community Leader). In the area, people's moral behavior was damaged by drug trafficking activities and the armed conflict. Thanks to the actions carried out, new values can be observed which have enabled people to start working together with trust and personal commitment.

An improvement in the ability to overcome conflicts has been emphasized as a key element. Workshops and community meetings during the implementation processes of the Transition Plans are the main tools for overcoming conflicts and tensions in a joint and participative manner, as they include everyone's opinions. Table 3 shows the key elements identified as part of the new model's effects. The results show a change towards improved trust between the agents involved, a collective action for constructing rural prosperity in the region of La Macarena. The 2503 families who have participated in the Transition Plans and in the substitution of illicit crops have committed to acting legally and not planting illicit crops again. This drives the illegal armed groups away from the area and ensures an ethical approach to their business activities. 


\subsection{Technical-entrepreneurial component: negotiation planning for projects}

The influence of the technical-entrepreneurial dimension is given a total score of $27.36 \%$ amongst the beneficiaries who were interviewed. This influence is based on the possibilities that the Alternative Development model offers in terms of creating a flow of goods and services for the inhabitants as a result of implementing projects. Throughout the years, the UACT has been working with communities, local authorities, international support, as well as public and private entities, in order to implement a group of investment projects through sectorial technical roundtables and cover the territories' needs.

From this technical-entrepreneurial point of view, the Transition plan and its actors have known how to design a strategy with a clear "business function" (Friedmann, 1987), aimed not only at substituting illicit crops, but also at creating production chains with an agribusiness focus as well as expanding knowledge and improving professional skills. The process has aimed to bring the private and public sectors and municipal governments closer together, creating a suitable environment for creating business projects by involving and negotiating with the inhabitants. This component is based on "Transactive planning" (Friedmann, 1987), which emphasizes the skill of "creating relationships" between the different parties involved throughout the agribusiness production chains. The planners of this new Alternative Development focus, coordinated by the UACT, identify the affected population as the "client", including them in the planning team itself in order to work "with" people. Table 4 shows the identified effects, from the technical-entrepreneurial point of view, resulting from the implementation of projects under the 'Transition Plans' framework.

The results primarily show the effect of innovation, in terms of solving problems and the diversification of new legal products and services for alternative development. Communal projects have facilitated mutual enrichment with regards to the design and implementation of new projects, developing skills for thinking and acting in an original and imaginative way (Cazorla and De Nicolás, 2014; De los Ríos et al., 2014). These multi-actor relationships have enabled planners' individual and collective creativity to be exploited, as well as the projects' beneficiaries, helping families and in support of the common good (Cazorla and De los Ríos, 2017). Innovations relating to the creation of new economic activities, which replace illicit crops, stand out, thanks to new projects for the production of cocoa, coffee, bananas, fruits as well as livestock.

Another relevant effect is the collective commercialization of products, which has been possible thanks to the trust that has been established between the agents involved: ". We now have a good production process...thanks to the trust there is, we are going to sell together, directly and without intermediaries" (Association Leader). The commercialization of milk, coffee and cocoa through cooperatives stands out as it has improved the viability of producing new legitimate crops. On the other hand, group projects based on transactive planning (Cazorla and De Nicolás, 2014) have strengthened families' commitment to take on new risks (Friedmann, 2005) and develop a new strategic vision for new businesses and ventures. These ventures have proved viable for many families, as the production chains include aspects relating to quality, improved techniques, efficient use of resources, joint efforts for including agents in the value chains, reduced production costs through cooperatives, as well as environmental sustainability and self-management in terms of production processes.

Producers' organizations, which are key actors in transactive planning, have been able to implement several strategic projects financed by the Government to improve the region's competitiveness through improved communication channels and production infrastructure, as well as access to new markets. Table A1 in Appendix A summarizes the projects implemented in the post conflict zone, which are a result of the negotiation processes and joint working between the planning team and inhabitants from the rural areas. These projects are presented based on the key elements of the strategy adopted in the alternative development model, which is driving economic development and the creation of rural prosperity. Table A2 in Appendix A, shows the resources invested in the projects in each of the Transition Plan's areas. The total amount invested in Colombian Pesos exceeds COP\$\$170.080.093.629, which is equivalent to USD\$65.415.421, at an exchange rate of COP\$2.600. As Table A2 shown, the majority of the investment relates to infrastructure improvements, especially in terms of highways, followed by the implementation of Social Development and Economic Development projects.

\section{Conclusion}

Colombia, Peru and Bolivia share a long history of ineffectual forced eradication, and failed alternative development initiatives. At the failure of these programs, emerging clearly universal values and future trends, this can be extrapolated to all approaches and all circumstances. This paper has presented a new methodological framework for substituting illicit crops in conflict areas, based on the "Working with People" (WWP) model, from planning as social learning. This WWP experience in Colombia provides evidence that process of social learning can be effective for substituting illicit crops in conflict areas, to alternative development projects by the public and private sectors.

After fifty years of armed conflict, the Government of Colombia and the Revolutionary Armed Forces of Colombia-People's Army, signed in November 2016 the "Agreement to End the Armed Conflict and Build a Stable and Lasting Peace. This historical agreement, learning from past

Table 4

Effects of the technical-entrepreneurial dimension.

Source: Own elaboration from fieldwork (Ávila Cerón et al., 2016). (Note that answers are neither inclusive nor exclusive).

\begin{tabular}{|c|c|c|c|c|}
\hline \multirow[t]{2}{*}{ Effects of The Technical-entreprenerial Dimension } & \multicolumn{4}{|c|}{ Level of influence } \\
\hline & 1 Very weak & 2 weak & 3 strong & 4 Very strong \\
\hline Innovation to solve problems, improve goods, services, products and technologies & $0 \%$ & $0 \%$ & $15 \%$ & $85 \%$ \\
\hline Collective commercialization of products & $0 \%$ & $0 \%$ & $20 \%$ & $80 \%$ \\
\hline Quality of goods and services & $0 \%$ & $0 \%$ & $22 \%$ & $78 \%$ \\
\hline Coherent vision and business strategy & $0 \%$ & $0 \%$ & $30 \%$ & $70 \%$ \\
\hline Improvements in the profitability of activities & $0 \%$ & $0 \%$ & $35 \%$ & $65 \%$ \\
\hline Technical improvements in the production process & $0 \%$ & $0 \%$ & $38 \%$ & $62 \%$ \\
\hline Entrepreneurship & $0 \%$ & $0 \%$ & $40 \%$ & $60 \%$ \\
\hline Environmental sustainability of production processes & $0 \%$ & $10 \%$ & $30 \%$ & $60 \%$ \\
\hline Efficient use of resources & $0 \%$ & $0 \%$ & $50 \%$ & $50 \%$ \\
\hline Joint efforts to equally distribute the value added in the value chain & $0 \%$ & $20 \%$ & $40 \%$ & $40 \%$ \\
\hline Individual commercialization of goods and services & $0 \%$ & $35 \%$ & $25 \%$ & $40 \%$ \\
\hline Autonomy in terms of factors of production & $30 \%$ & $60 \%$ & $10 \%$ & $0 \%$ \\
\hline Reduced production costs & $30 \%$ & $70 \%$ & $0 \%$ & $0 \%$ \\
\hline Diversification of products and services & $40 \%$ & $60 \%$ & $0 \%$ & $0 \%$ \\
\hline
\end{tabular}


mistakes, is the official recognition of a new a conceptual proposal. Following these years, the WWP model's potential has been validated in the framewoik peace agieement between the Colombian Goveinment and the FARC-EP guerrillas, and it's an opportunity to initiate a new phase of transition in Colombia. The validation process culminates in the recent ptocess of 'handing over weapons and transitioning to legality'. The process started in January 2017 and was agreed between the Government and FARC-EP negotiation teams, setting the scene for prosperity. The implementation of the model has created a set of pro. jects and actions which are having a direct impact on the key factors defined in national policies and the Peace Accord between the Colombian Government, in order to achieve alternative development and create prosperity.

Compared to the traditional focuses of the Alternative Development programs implemented at the start of the 1960s and 1970s in the Andean region, the model implemented validate a new focus for creating prospetity in post conflict zones, based on social learning and aligned with National Policies for consolidation, territorial reconstruc. tion, eradication of illicit crops and alternative development. The ex. perience in Colombia demonstrates that the WWP model enables links to be established between the population and the governments, which are based on tiust and weaken the armed gtoups and drug trafficking. Of course this does not mean that WWP approach is always optimal in every context; multiple ways and approaches can be combined, even with the blueptint appioaches, in order to substitute illicit crops. The approach opens up the possibility of new research questions and new approaches to lighten existing questions for substituting lllicit clops in conflict areas and in alternative development planning theory. Considering the international framework, new researches questions can be broadly considered, equilibtium between the three dimensions of WWP model: political-contextual, ethical-social and technical-entrepreneurial.

First questions are in connection with the political-contextual dimension of the alternative development programs. This dimension contibuting to a strategic vision that reaches tutal prosperity, improving the coordination and management of resoutces, the creation of synergies and consolidation of citizen security through the institutional presence in the territories. The creation of prosperity in the affected communities is only possible if the alternative development programs include a baseline aimed at restoring secutity and rule of law, as a coinerstone of governance and sustainable development. However, the best approach for any particular circumstance is dependent on the specific context. Unfortunately, most national and international devel. opment agencies assume that there is one approach (their existing policy) which is the best and they miss the essential first stage, not asking the question: what type of intervention apploach is best suited to this type of issue in this context? The territorial-based approach of the models involves recognition and consideration of the economic, cultural and social needs, chatacteristics and peculiatities of tetritoties and communities, thereby guaranteeing socio-envitonmental sustainability. Furthermore, it involves the active patticipation of all citizens and sectors of society for implementing the various projects comprehen. sively and in a coordinated way. Under this conceptual framework, rutal prospetity is understood to be a concept, which includes multiple social, environmental and economic dimensions. The global diugs problem should be analyzed in the same way; linked to all the aspects of sustainable development. From this dimension, models must include efficient mechanisms for conciliation and conflict resolution concerning land use and possession, aimed at guaranteeing effective protection of rutal propetty tights; resolving conflicts conceining tights of land possession and use; and, in general, promoting the legalisation of rural property, including traditional mechanisms and participative intervention by communities in conflict resolution. In the face of these need to improve land ownership governance, the FAO Voluntary Guidelines on the Responsible Governance of Tenule of Land, Fisheties and Forests (VGGT) in the Context of National Food Security, should be very present from all stakeholders. In the same way as in the WWP model, focusing on dialogue and negotiation among the actors involved, it is considered by FAO as a key aspect for the implementation of VGGT. This VGGT can be successfully implemented using the WWP intervention strategy, which has been analyzed in the presented case study, since the apptoach of dialogue and negotiation between the involved stakeholderst, considered by the VG are consistent with the WWP approach. Specially, consultation and participation are essential to contribute to responsible governance of tenure of land, taking into consideration existing power imbalances between different parties.

Secondly, decades of conflict have led to deep mistiust within society, especially in the tertitoties most affected by the conflicts. A second type of questions are related to the ethical-social dimension, and enables us to consider topics of how to build trust, how created new effective forms of collaboration and knowledge exchange, which have impioved behaviors and values amongst the population. These changes lay the foundations for the producers and families being able to work together with public leaders in order to move a step closer to substituting illicit crops and achieving prosperity in the communities. The change in behavior and creation of values based on trust is a complex and lengthy process which requites long-term actions coupled with strategies aimed at breaking up illegal and violent organizations throughout the drug trafficking chain. Through working with people, the participation of and dialogue between the various sectors of society will conttibute to building a climate of trust and promoting a cultute of tolerance, respect and peaceful coexistence in general. Is not an easy task but requites the perseverance and credibility of political actors, from this ethical dimension. This trust between people contributes to greater social inclusion, territorial integration and to strengthening prosperity and demociacy, ensuting that social conflicts can be resolved thtough wotking with people. Patticipation by society in the peacebuilding process is essential and in particular, its involvement in the planning, execution and monitoring of territorial-based plans and programs - which is also a guarantee of transparency.

A thitd type of research questions to WWP planning enables us to consider topics related to the technical-entrepreneurial dimension. From this dimension must be consider topics of how to implemented alternative projects that generate economic development, responding in an effective, opportune and timely manner in order to form strong associations (producer organizations). Alteinative production initiatives (instead of illicit ctops) should provide a source of income for families, creating employment opportunities for farmers and the rural population. From WWP process approach is conceiving innovation as a process of social learning that includes an open and interactive process with an important social dimension, which means a constant adaptation of the foims of knowledge and learning to the market and technological conditions constantly changing. Innovation is seen not just in terms of technology and efficiency, but also, in new products, new business models as well as in social, organizational, institutional innovation, and how farmers are actively exploring alternatives in production methods and resource uses in order to maintain their livelihoods. Duting this innovation process, the government's local resources and international support could be require to jointly co-finance the projects, with bottomup approach and seeking a balance between the different dimensions of rural prospetity.

Finally, the alternative development models and substituting illicit crops in conflict areas must continually search provide the planning process with an integrating element which guarantees social learning spaces amongst different sub-systems, which means they can learn ftom the real drivers of change: the population affected by the legal economy linked to the production of illegal crops. Peace building and consolidation, within the context of the solution of the conflicts, require the extension of democracy to incorporate new social actors on the political scene, thereby enriching debate and thus consolidating pluralism and the representation of society's diverse visions and interests. These participatory and democratic processes improve people's skills and 
competences, incorpotating ethics and values as fundamental elements for being able to wotk in teams, creating conditions of well-being and quality of life for the rural population, contitbute to the etadication of poverty, promote equality and ensure full enjoyment of the rights of citizenship.

In summaty, the WWP model is an experimental way of tackling Altemative Development in Colombia, based on a tertitorial focus, creating trust and reinforcing the participating governments' structures. The WWP model for substituting illegal crops in post conflict zones goes beyond the traditional focuses of Alternative Development, which have failed to achieve institutional trust or create prosperity. This study validates the fundamental aspects of an alternative development model in Colombia, based on its implementation in six local municipalities.

\section{Acknowledgements}

The authors would like to thank the people of La Macarena for their participation, as well as the managers of the PCIM (Plan de Consolidación Integral de la Macarena, Centro de Coordinación de Acción Integral del Ministerio de la Defensa Nacional del Gobierno de Colombia), the Provincial Center for Agribusiness Management (CPGA), the Regional Government of Meta and the United States Agency for International Development (USAID) for their participation and theit constiuctive comments and suggestions.

\section{Appendix A}

Table A1

Projects implemented by the PCIM in the region of La Macarena.

Source: Administrative Unit for Terrtorial Consolidation Management Report. 2015.

\begin{tabular}{|c|c|c|}
\hline Economic Development Projects & Partner & Beneflciarles \\
\hline Access to commercialization channels for milk & Private Company "Alquerla y Recreo" & 175 families \\
\hline Microcredit for production organizations & National Government- UABCT - Agricultural Bank & 620 families from 16 organizations \\
\hline Comprehensive technical support for producers & $\begin{array}{l}\text { Ministy of Agriculture } \\
\text { Associations of Producers }\end{array}$ & 2.503 producers \\
\hline 19 projects with agribusiness production alliances & $\begin{array}{l}\text { Ministry of Agriculture, Regional Government of Meta, Mayor's Offlces } \\
\text { and international cooperation }\end{array}$ & 760 small producers \\
\hline $\begin{array}{l}\text { Rural opportunity projects } \\
\text { Rural capitalization projects } \\
\text { Improved production infrastructure for milk and coffee } \\
\text { collection centers }\end{array}$ & $\begin{array}{l}\text { Ministry of Agriculture. Mayor's Offices and international cooperation } \\
\text { Department for Rural Prosperity DPS } \\
\text { Regional Government of Meta, Mayor's Offlces and international } \\
\text { cooperation }\end{array}$ & $\begin{array}{l}310 \text { producers from } 13 \text { associations } \\
270 \text { producers from } 12 \text { associations } \\
1650 \text { producers from } 8 \text { collection } \\
\text { centers }\end{array}$ \\
\hline Business plans for entrepreneurship & $\begin{array}{l}\text { International cooperation } \\
\text { Regional Govemment of Meta. Associations of Producers }\end{array}$ & 1650 producers from 30 associations \\
\hline
\end{tabular}

\begin{tabular}{|c|c|c|}
\hline Infrastructure \& Connectivity & Partner & Beneficiartes \\
\hline $\begin{array}{l}\text { The 'Via Marginal de la Selva' highway in la Macarena \& San Vicente } \\
\text { del Caguan }\end{array}$ & $\begin{array}{l}\text { National Government } \\
\text { Local Governments }\end{array}$ & $195 \mathrm{~km}$ of highway \\
\hline 'Transversal de la Macarena' highhway: Surface and widening works & $\begin{array}{l}\text { National Government } \\
\text { Military Engineering } \\
\text { Governments of San Juan de Arama, Mesetas \& Utbe }\end{array}$ & $84 \mathrm{~km} \& 23.350$ inhabitants \\
\hline Bridge construction projects & $\begin{array}{l}\text { Regional Government of Meta Governments of Vistahermosa, } \\
\text { Urlbe, Mesetas }\end{array}$ & $\begin{array}{l}5 \text { Bridges built } \\
32,472 \text { inhabitants }\end{array}$ \\
\hline $\begin{array}{l}\text { Improved tertiary roads in areas prioritized under "Colombla Responds" } \\
\text { "Rapid Response Program": } 33 \text { Social infrastructure prọlects in 'veredas' } \\
\text { In the Transition Zones }\end{array}$ & $\begin{array}{l}\text { Local governments } \\
\text { Administrative Unit for Territorial Consolidation, United } \\
\text { Nations Office on Drues and Crime }\end{array}$ & $\begin{array}{l}150 \mathrm{Km} \text { of roads for } 29.000 \text { inhabitants } \\
2.508 \text { inhabitants from } 6 \text { of the }\end{array}$ \\
\hline Highway improvement projects, paving urban roads & $\begin{array}{l}\text { Military Engineers } \\
\text { Governments of La Macarana y Puerto Rico }\end{array}$ & $15 \mathrm{~km}$ of roads and 2 new bridges \\
\hline $\begin{array}{l}\text { Electrical connection in the rural areas of Vistahermosa, Puerto Rico. } \\
\text { San Juan de Arama La Macarena. }\end{array}$ & $\begin{array}{l}\text { National Government } \\
\text { Regional Governments Macarena -Private Company Las } \\
\text { Delicias "Electrocaqueta" }\end{array}$ & $166 \mathrm{Km}$ of power lines \\
\hline
\end{tabular}

\begin{tabular}{|c|c|c|}
\hline Social Development & Partner & Beneficiarles \\
\hline \multirow[t]{2}{*}{$\begin{array}{l}\text { Improve long.term infrastructure and education centers in } \mathbf{5 4} \\
\text { 'veredas' }\end{array}$} & National Government & 2.503 families from 54 rural district groups. \\
\hline & $\begin{array}{l}\text { Regional Government of } \\
\text { Meta } \\
\text { International Cooperation }\end{array}$ & \\
\hline \multirow[t]{2}{*}{$\begin{array}{l}\text { Resources in } \mathbf{5} \text { Education Centers in the 'veredas' which are the focus } \\
\text { of the Transition Plans }\end{array}$} & National Government & 2.503 families from 54 'veredas' \\
\hline & $\begin{array}{l}\text { Regional Government of } \\
\text { Meta }\end{array}$ & \\
\hline Improve Infrastructure in 6 Health Centers & $\begin{array}{l}\text { National Government } \\
\text { Regional Government of } \\
\text { Meta }\end{array}$ & 2.503 families from 54 'veredas' \\
\hline
\end{tabular}




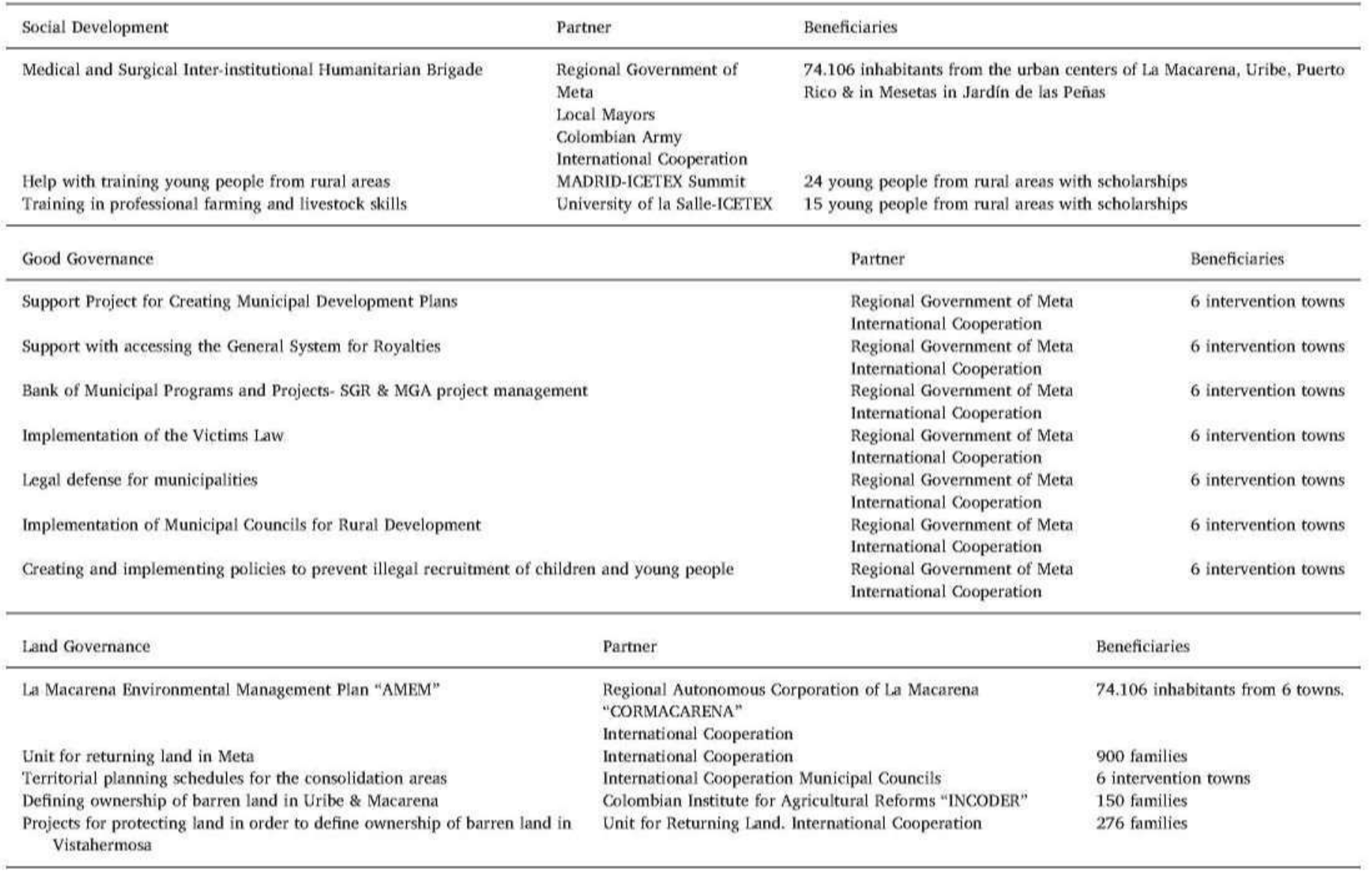

Table A2

Financing of Strategic projects (in Colombian Pesos).

Source: Administrative Unit for Territorial Consolidation Management Report, 2016.

\begin{tabular}{|c|c|c|c|c|c|c|}
\hline TOWN & Good Governance & Land Governance & Economic Development & Infrastructure & Social Development & Total \\
\hline Vista Hermosa & $\$ 442.204 .389$ & $\$ 2.380 .425 .000$ & $\$ 4.003 .788 .153$ & $\$ 9.908 .922 .211$ & $\$ 1.549 .526 .359$ & $\$ 18.284 .866 .112$ \\
\hline Uribe & $\$ 442.204 .389$ & $\$ 2.380 .425 .000$ & $\$ 800.660 .840$ & $\$ 29.234 .630 .385$ & $\$ 23.893 .626 .635$ & $\$ 56.751 .547 .249$ \\
\hline Puerto Rico & $\$ 442.204 .389$ & $\$ 2.380 .425 .000$ & $\$ 5.964 .866 .034$ & $\$ 39.143 .552 .596$ & $\$ 723.269 .660$ & $\$ 48.654 .317 .679$ \\
\hline La Macarena & $\$ 442.204 .389$ & $\$ 2.380 .425 .000$ & $\$ 5.987 .586 .134$ & $\$ 4.315 .134 .483$ & $\$ 2.331 .479 .421$ & $\$ 15.456 .829 .427$ \\
\hline Mesetas & $\$ 442.204 .389$ & $\$ 2.380 .425 .000$ & $\$ 4,344.370 .737$ & $\$ 1.794 .611 .866$ & $\$ 255.125 .872$ & $\$ 9.216 .737 .864$ \\
\hline San Juan & $\$ 442.204 .389$ & $\$ 2.380 .425 .000$ & $\$ 3.764 .866 .034$ & $\$ 14.745 .030 .215$ & $\$ 383.269 .660$ & $\$ 21.715 .795 .298$ \\
\hline TOTAL & $\$ 2.653 .226 .334$ & $\$ 14.282 .550 .000$ & $\$ 24.866 .137 .932$ & $\$ 99.141 .881 .756$ & $\$ 29.136 .297 .607$ & $\$ 170.080 .093 .629$ \\
\hline
\end{tabular}

\section{References}

Ávila Cerón, C.A., De los Rios-Carmenado, 1., 2017. Alternative development in rural communities affected by the illegal economy: the case of La macarena (Colombia), In: Nicolae, I., De los Ríos, L., Vasile, J.A. (Eds.), Rural Communities in the Global Rconomy: Beyond The Classical Rural Economy Paradigms. Nova Science Publishers, Inc, New York, pp. 23-38.

Ávila Cerón, C,A., De los Ríns.Carmenado, L. Marrin. S., 2016. Effects of alrernative de. velopment in Colombia: an analysis of the macarena consolidation plan from working with people. In: Chivu, L., Ciutacu, C., Ioan-Franc, V., Vasile, J.A. (Eds.), Economic Dynamics and Sustainable Development-Resources, Factors, Structures and Policies. Peter Lang Publishing, New York, pp. 171-198.

Argyris, C., Schon, D, 1978. Organisational Learning: A Theory of Action Perspective, Addison Wesley Reading, MA.

Armenteras, D., Rudas, G., Rodríguez, N., Sua, S., Romero, M., 2006. Patterns and causes of deforestation in the Colombian Amazon. Ecol. Indic, 6, 353-368.

Balcázar, A. Rodrfiquez, C, 2013. Tierra para uso ggropecuario, In: Perfetri, J, Baleázar, A., Hernández, A., Leibovich, J. (Eds.), Políticas para el desarrollo de la agricultura en Colombia. Fedesarrollo, Sociedad de Agricultores de Colombia (SAC), Incoder, Finagro, Banco Agrario, pp. 248.

Balcázar, A., 2008. Transformaciones en la agricultura colombiana entre 1990 y 2002. Revista de Economía Institucional 5 (9).
Bond, R., Hulme, D., 1999. Process approaches to develepment: theory and Sri Lankan practice. World Dev, 27, 1339-1358.

Bradley, A.V.. Miflington. A.C., 2008. Coca and colonists: quantifying and explaining forest clearance under coca and anti-narcotics policy regimes. Ecol. Soc, 13 (1), 31 ,

Briones, A. Cumsille, F. Henao, A. Pardo, B., 2013. The Drug Problem in the Americas: Analytical Report. Organization of American States General Secretariat, Washington, D.C.

Bromley, D., 2008. Formalising property relations in the developing world: the wrong prescription for the wrong malady, Land Use Policy 26, 20-27.

Buxton, J., 2015. Drugs and development the great disconnect. Global Drug Policy Observatory. Swansea University.

Cazorla, A., De Nicolás, V.L., 2014. Planning and projects: three visionaires Friedmann, J. Trueba, 1. and Ramos, A. Project Manage. Eng. Res. 277-289 (Lecture Notes in Management and lndustrial Engineering).

Cazorla, A. De los Rfos, I., 2017. Rural Community Management in the Global Economy: a planning model based on innovation and Entrepreneurial Activity. In: Nicolac, 1. De los Ríos, L., Vasile, J.A. (Eds.), Rural Communities in the Global Economy: Beyond The Classical Rural Ẽconomy Paradigms. Nova Science Publishers; New York, pp. $1-22$.

Cazorla, A.I., De los Ríos-Carmenado, I. Díaz-Puente, J.M., 2005. The LEADER community initiative as rural development model: application in the capital region of Spain. Agrociencia 39, 697-708.

Cazorla. A., De los Ríos. L. Salvo. M. 2013. Working with people, in rural development projects: a proposal from social learning. Cuadernos Desarrollo Rural $10(70)$. 
131-157.

Cernea. M, 1991. Putting People First: Sociological Variabies in Rural Development. Oxford University Press Books, New York, pp. 575.

Clemencia, M. Lemus, R., Stanton, K. Walsh, I. et al. 2005, Colombia: a vicious circle of drugs and war. In: Coletta Youngers, A., Rosin, Eileen (Eds.), Drugs and Democracy in Latin America: The Impact of US Policy, Pp. 61-97 (London).

Coletta, A., 2005, Youngers and eileen rosin, the US "War on drugs": its impact in latin america and the caribbean. In: Youngers, C.A., Rosin, Rileen (Eds.), Drugs and Democracy in Latin America: The Impact of US Policy, pp. 1-13 (London).

Dávalos, L., Bejarano, A. Hall, M., Correa, H., Corthals, A., Espejo, O., 2011. Forests and drugs: coca-driven deforestation in tropical biodiversity hotspots. Environ. Sci Technol. 45 (4), 1219-1227.

DANE, 2015. Departamento Administrativo Nacional De Estadísticas, Boletín De Prensa, Principales Indicadores Del Mercado Laboral. DANE, Bogotá, D.C.

Darnhofer, I., De los Rios, I., Knickel, K., Koopmans, M., Lamine, C., Almored, G., Tisenkopfs, T., 2014. Rethinking the Links Between Farm Modernization. Rural Development and Resilience in a World of Increasing Demands and Finite Resources.

De los Rios, I., Diaz-Puente, J., Cadena-lniguez. J., 2011a. The initiative L.EADER as a model for rural development: implementation to some territories of México. Agrociencia 45 (5), 609-624.

De los Rios, 1., Cadena-, J., Diaz, J.M., 2011b. Creating local action groups for rural development in México: methodological approach and lessons learned. Agrociencia 45 , 815-829.

De los Ríos, I., Turek, A., Afonso, A., 2014. Project management competencies for regional development in Romania: analysis from working with people model. Procedia Fcon. Finance 8, 614-621.

De los Ríos, L., Ortuño, M., Rivera, M., 2016a. Private-public partnership as a tool to promote entrepreneurship for sustainable development: WWP torrearte experience. Sustainability $8,1-19$.

De los Rios, 1. Rivera, M. García, C. 2016b. Redefining rural prosperity through social learning in the cooperativesector: 25 years of experience from organic agriculture in Spain. Land Use Policy 54, 85-94.

De los Ríos-Carmenado, 1., Guillén, J., Herrera, A.T., 2013. Complexiry in the management of rural development projects: case of LASESA (Spain). Int. J. Rural Dev. 10 167-186.

DeBecka, K.. Wooda, E., Montanera, J., Kerra, T., 2009. Canada's new federal 'Nationa Anti-Drug Strategy': an informal audit of reported funding allocation. Int. J. Drug Policy 20 (2), 188-191.

Dion, M.L., Russler, C., 2008. Eradication efforts, the state, displacement and poverty: explaining coca cultivation in colombia during plan Colombia. J. Latin Am. Stud. 40, 399-421.

Echandia, C., 2011. Situación actual de las FARC: un análisis de los cambios en las es. trategias y la territorialidad (1990-2011). Fundación Ideas para la Paz. Series Informes 13.

Etter, A. McAlpine, C., Wilson, K., Phinn, S., Possingham, H., 2006. Regional patterns of agricultural land use and deforestation in Colombia. Agric. Ecosyst. Environ. 114 (2), $369-386$.

Etzioni, A., 1968. The Active Society: A Theory of Societal and Political Processes. Free Press, Nueva York.

FAO, 2012. Food and Agriculture Organization Voluntary Guidelines on the Responsible Governance of Tenure of Land, Fisheries and Forests in the Context of National Food Security. United Nations Press, Rome, pp. 431.

Farthing, L., Kohl, B., 2005. Conflicting agendas: the politics of development aid in drug. producing areas. Dev, Policy Rev, 23 (2), 183-198.

Fjeldså, J., Álvarez, M., Lazcano, J., León, B., 2005. Illicit crops and armed conflict as constraints on biodiversity conservation in the andes region. AMBIO: J. Hum. Environ. 34 (3), 205-211.

Franco, S., 2010. Lineamientos de un programa de ordenamiento de la propiedad rural en la zona de la Macarena. Programa MIDAS -USAID.

Friedmann, J., 1987. Planning in the Public Domain. From Knowledge to Action Princeton University Press. Princeton, N.J.

Friedmann, J., 2005. Globalization and the emerging culture of planning. Progr. Plann. 64 (3), 183-234

Gómez, S., Soto, F., 2013. eflexiones sobre la concentración y extranjerización de la tierra en América Latina y el Caribe. FAO, Roma.

Gootenberg. P., 2012. Cocaine's long march north, 1900-2010, Latin Am, Polit. Soc. 54 (1) $159-180$

Gootenberg, P., 2014. Peruvian cocaine and the boomerang of history North American. Congr. Latin Am. 47 (3), $48-49$.

Grisaffi, T., Ledebur, K., 2016. Citizenship or repression? Coca, eradication and devel. opment in the andes. Stab. Int. J. Secur. Dev, 5 (1), 1-19.

Habermas, J., 1996. Three normative models of democracy, In: Benhabib, S. (Ed.) Democracy and Deference. Princeton University Press, New York, pp. 21-30.

Holmes, J.S., Pineres, S.A., Curtin. K.M., 2006. Drugs, violence, and development in Colombia: a department level analysis. Latin Am. Polit. Soc. 48 (3), 157-184.

Housego, K., 2005. Colombian Cocaine Blight Spreads into Nature Parks, Threatening Their Survival. Associated Press (September 27).

Jackson, T., Anderson, V., 2009. Redefining Prosperity - Essays in Pursuit of a Sustainable Fconomy Sustainable Development Commission. Earthscan. London.

Kasser, T., 2007. A Vision of Prosperity. Think-piece for the SDC's Redefining Prosperity Project. Sustainable Development Commission, London.

Knickel, K., 2016. Trajectories of agricultural modernization and rural resilience: some first insights derived from case studies in 14 countries. Appl Stud. Agribus. Commer. 10. $31-34$

Legatum Institute, 2013. Prosperity Index 2013, URL http://www.prosperity,com/(accessed 21.10.14.).

Lindblom, C.E., 1977. Politics and Markets: The Worlds Political-Economics Systems Basic Books, New York.

Lupu. N., 2004. Towards a new articulation of alternative development: lessons from coca supply reduction in Bolivia. Dev. Policy Rev. 22 (4), 405-421.
Mansfield, D., 1999. Alternative Development: the modern thrust of supply-side policy, Bull. Narc. 51 (1), 19-43.

Mansfield, D., 2011. Assessing supply-Side policy and practice: eradication and alternative development. In: Working Paper for the First Meeting of the Giobal Commission on Drug Policy. Geneva 24-25 Jan 2011.

McQuaid. R.W., 2002. The theory of partnership. In: Osborne, S. (Ed.), Public-private Partnerships: Theory and Practice in International Perspective. Routledge, London, UK, pp. 9-35.

Midgley, J., 1995, Social Development: The Developmental Perspective in Social Welfare. Sage.

Moreno, R., Kraybill, D.S., Thompson, S.R., 2003. An econometric analysis of coca eradication policy in Colombia. World Dev. 31 (2), 375-383.

Naoum, S., 2003. An overview into the concept of partnering. Int. J. Proj. Manage. 1. 71-76.

Norton, R.D., Balcazar, A.V., 2003. A Study of Colombia's Agricultural and Rura Competitiveness. Report to United Nations Food and Agriculture Organization. The World Bank and United States Agency for International Development, Washington DC, USA.

OACP (Oficina del Alto Comisionado de Paz), 2016. Final agreement to end the armed conflict and build a stable and lasting peace.

ONU, 2013. Los Conflictos Armados. (Obtenido el 20 de abril de 2017, de Las Naciones Unidas y la asistencia humanitaria: http://www.un.org/es/humanitarian/overview/ conflict.shml File acessed: May, 2017).

Ortiz, C.E., 2003. Cultivos ilícitos y nueva ruralidad en Colombia, Cuadernos de Desarrollo rural 50, 144-166.

Ostrom, E. 1998. A behavioral approach to the rational choice teory of collective action. Presidential adress, American Political Science Association. Am. Polit. Sci. Rev, 92 (1), 1-22.

Pêrez Correa, E., 1998. A vision of rural development in Colombia. Cuadernos de Desarrollo Rural 41, 7-20.

Peceny, M. Durnan, M. 2006. The FARC's best friend: U.S. antidrug policies and the deepening of Colombia's civil war in the 1990. Latin Am. Polit. Soc, 48 (2), 95-116.

Perfetti, J., Hernández, A., Leibovich, J., Balcázar Á, 2013. Poláticas para el desarrollo de la agricultura en Colombia. SAC y Fedesarrollo. Bogotá, D. C. 248.

Philo, C., 1993. Postmodern rural geography? A reply to Murdoch and Pratt. J. Rural Stud. 9, 429-436.

Rapp, H., 2008. Fulfilment and Prosperity: A New-gandhian Vision. Fourth OpinionPiece for the Redefining Prosperity Seminar Visions of Prosperity. Sustainable Developmen Commission, London. http://Www.sd-commission.org.uk/publications.php?id $=737$

Reyes, A. 2008. Guerreros y Campesinos: E.l despojo de la tierra en Colombia

Ritter, A., 2009. Policy Analysis: Illicit drugs policy through the lens of regulation. University of New South Wales, Sydney, NSW 2052, (Australia).

Rivera, M., Knickel, K., De los Rios, I., Ashkenazy, A., Qvist Pears, D., Chebach, T. Sumane, S., 2017. Rethinking the connections between agricultural change and rura prosperity: a discussion of insights derived from case studies in seven countries. J. Rural Stud(Available online 10 August 2017. in press, Corrected Proof) http://www sciencedirect.com/science/article/pii/S0743016716302108?via\%3Dihub.

SDC, 2009. Prosperity Without Growth? The Transition to a Sustainable Economy. Sustainable Development Commission, London. http://www.sdcommission.org.uk publications.php?id $=914$.

Salas, L.G.. 2010. Corredores y territorios estratégicos del conflicto armado en Colombia Prospectiva Geográfica 15 (1), 9-36 (Colombia).

Sardar, Z., 2007. Prosperity: A Transmodern Analysis, Think-piece for the SDCSeminar Visions of Prosperity. Sustainable Development Commission.

Sastre-Merino, S.. De los Rios, 1., 2002. Capacity building in development projects. Procedia Soc. Behav. Sci, 46, 960-967.

Schumacher, E.F. 1976. Small Is Beautiful: a Study of Ficonomics as If People Mattered. Universidad de Michigan. Abacus.

Senge, P., Kliener, A., Roberts, C., Ross, R., Roth, G., Smith, B., 1999. The Dance of Change: The Challenges of Sustaining Momentum in Learning Organisations. Doubleday, New York.

Serra, M.L. 2010. Hacia una protección efectiva de los derechos humanos de niños y ainas en el conflicto armado. Universitas. Revista de Filosofia, Derecho y Politica.

Singer, M., 2008. Drugs and Development: The Global Impact of Drug Use and Trafficking on Social and Economic Development. Hispanic Health Council, Hartford, USA.

Steven, R.B., 2000, Drugs and Drug Policy in America: A Documentary History. Greenwood Publishing Group. Westport, USA, pp، 408.

Stratta, R., De los Rios, 1., González, M.. 2017. Developing comperencies for rural development project management through local action groups: the punta Indio (Argentina) experience, In: Appiah-Opoku, S. (Ed.), International Development. InTech, New York, pp. 153-172.

Suarez, A., Árias, P., Martínez, B., 2017. Environmental sustainability in post-conflict countries: insights for rural Colombia. Environ. Dev. Sustainabiliry 2017, 1-19.

Šumanea, S., Kundaa, I., Knickel, K., Straussc, A., Tisenkopfsa, T., De Ios Rios, I., Rivera, M.. Chebache, T., Ashkenazyf, A., 2017. Local and farmers' knowledge matters! How integrating informal and formal knowledge enhances sustainable and resilient agriculture. J. Rural Stud. Available online 10 August 2017 In Press, Corrected Proof http://www.sciencedirect.com/science/article/pii/S0743016716302194.

Thoumi, F., 2002. Illegal drugs in Colombia: from illegal economic boom to social crisis Ann. Am. Acad. Polit Soc. Sci, 582 (1), 102-116.

UACT, 2017. Administrative Unit for Territorial Consolidation. Unidad Administrativa para la Consolidación Territorial. Gobierno Nacional del Colombia(url: http://consolidacion.gov.co/?q = content/misión-y-vision, Fileaccessed: April, 2017) http:// www.consolidacion gov.co/?q = content/unidad-administrativa-para-la-consolidac $\%$ C3\%B3n-territorial-uact.

UNODC, 2005. Alternative Development A Global Thematic Evaluaiton. United Nations Office on Drugs and Crime, New York.

UNODC (. Enited Nations Office On Drugs And Crime), 2016. Monitoreo de territorios afectados por cultivos ilícitos, United Nations Office on Drugs and Crime New York. United Nations / Government of Colombia 151 pp. 
Van der Ploeg, J.D., van Broekhuizen, R., Brunori, R., Sonnino, R., Knickel, K., Tisenkopfs, T., Oostindie, H., 2008. Towards a framework for understandingregional rural development. In: van der Ploeg. J.D., Marsden, T. (Eds.), Unfolding Webs: The

Dynamics of Regional Rural Development. Royal VanGorcum, Assen (NL), pp. 1-28.

Vargas, R., 2002. The anti-drug policy, aerial spraying of illicit crops and their social,

environmental and political impacts in Colombia. J. Drug Issues 22 (4), 11-60.

Vargas, R., 2005. Strategies for controlling the drug supply: policy recommendations to deal with illicit crops and alternative development programs. J. Drug Issues 35 (1), 131-150.

Veillette, C., 2005. Plan Colombia: A Progress Report. February 17. Congressiona Research Service, Library of Congress, Washington, DC.

Wilson, S., 2002. Colombian Army's Clash with Paramilitary Troops May Be an Aberration 18 Washington Post. 